\title{
The Characteristics of Women's Image in A Novel of Entrok by Okky Madasari: A Study of Literary Criticism in Ideological Feminism
}

\author{
Irna Fitriana \\ Universitas Negeri Makassar, Jln. Bonto Langkasa, Kampus Gunung Sari, Makassar, South Sulawesi, Indonesia \\ Achmad Tolla \\ Universitas Negeri Makassar, Jln. Bonto Langkasa, Kampus Gunung Sari, Makassar, South Sulawesi, Indonesia \\ Jasruddin \\ Universitas Negeri Makassar, Jln. Bonto Langkasa, Kampus Gunung Sari, Makassar, South Sulawesi, Indonesia \\ Mahmudah \\ Universitas Negeri Makassar, Jln. Bonto Langkasa, Kampus Gunung Sari, Makassar, South Sulawesi, Indonesia
}

\begin{abstract}
This research aims at revealing the image characteristics of a transitional and feminist woman in a novel by Okky Madasari through ideological feminist literary criticism. This research uses qualitative descriptive method where 'Entrok' novel by Okky Madasari becomes as the data source. Technique of data collection applied is content analysis, while technique of validity is source triangulation. For technique of data analysis used in this research is an interactive analysis model with three components of data reduction, data presentation, and conclusion drawing. The findings discover two main things, that is the image of a transitional and feminist woman. In the story, Sumarni is a female figure who plays as a transitional woman as well as the image of a feminist woman.
\end{abstract}

Index Terms - image, novel, feminist literary criticism

\section{INTRODUCTION}

The discussion of women matter in literary works is not a novel thing in Indonesia or even throughout the world. In Indonesia itself, since the 1920 s, many authors began to make women as objects for themes of literary works, both novel and poetry.

If we take a look at the phenomena occuring in the empirical and fictional world, apparently there is no differences that women to this modern era still receive unequal treatments in society. Even undoubtedly many women have taken part in public and holding important roles, there are still discrimination experienced in every sector.

From that point, an awareness emerged where women should be appreciated. They want equality. Women are increasingly aware of their fate, rights, and ideals. This awareness is getting better with the support of parents and the current friendly environment. Seemingly parents and society have already accepted women's existence and abilities.

Indonesian women nowadays have mostly gained equality with men. This is evidenced by any selection of students, college students, or employees where no female applicant limitation.

Then what about women's struggle in the field of literature? It turned out that the phenomena of female rebellion had emerged. So far, the number of Indonesian literary books is very few, especially when compared with other countries. However, this few fictional works have the power to attract public attention (Purwanti, 2009).

The idea of feminism in Indonesian literary works has started since the 1920s. The phenomenal novel of Siti Nurbaya by Marah Rusli has brought women as the main issue, although the theme is about custom but still involves women. In line with that, another novel of Layar Terkembang by Sutan Takdir Alisyahbana where feminism has been represented through the character of Tuti. Up to now, the writers have not stopped carrying the feminism issue in their works.

Similarly, the novel Entrok by Okky Madasari strongly discusses about women, especially those related to the image. Therefore, this paper will reveal about the image characteristics of a transitional and feminist woman.

Several previous researches have revealed a numerous women and their problems through feminist perspective. For example Hui-Chun's writing (2014), "The Impact of the Feminist Heroine: Elizabeth in Pride and Prejudice" where it critically examines the feminist significance of Elizabeth Bennet about other portrayed female characters who in accordance with socially applied gender norms in England, while Elizabeth thoroughly stands against gender inequality. Literary works especially written by women have never been separated from feminism issue. 
Pursuing this further, a research by Rahmani (2015) who discovers the suppression of black women in the novel by Toni Morrison and leads her to use the theory of black feminism. The suppression of immorality are mostly endured by black women compared to white women.

An article by Vanita (2015) entitled Draupadi: An Epitome of Feminine Assertion in Chitra Banerjee Divakaruni's The Palace of Illusions where it describes about the study of Draupadi's perspective in Mahabharata and its struggle to liberate from the oppression. This surely looks from a feminist perspective as well.

Another article entitled "Gender Issues Discussed in Sri Lankan and Indian Plays: Special Reference to Edirivira Sarachcahndra's 'Maname' and Jaishankar Prasad's 'Dhruvasvamini' by Chandrasekara (2016) tries to identify how gender issues arise in two different countries and how they are reflected in the Sri Lankan and Indian dramas where evidently show that these two Asian playwrights have been influenced by gender and western theories used in their works.

Furthermore, Shebat (2016) in an article of "Women Empowerment in the Realms of Institutionalized Religion and Patriarchy: El Saadawi's Firdaus and Yezierska's Sara as Examples" finds two female figures in two different novels namely Firdaus and Sara who experiencing injustice caused by religion and social structure. Nevertheless, the two female figures manage to manumit the big problems they encounter.

Similar to it, Khurana (2016) writes "A Gynocritical Reading of Nalini Jameela's The Autobiography of a Sex Worker and Amen: The Autobiography of a Nun by Sister Jesme” where it highlights that one of the striking alienations in the literary tradition ignores and degrades women's experience to a non-consequentialist place in the literary canon.

Women suppression can also be seen in the work of Contemporary Malaysian writers with the two short stories of The Silk Fan and Di bawah Blanket showing the "gender issues" in defying gender expectation of their sexuality (Noor, 2017).

\section{A. Novel}

The fictional work in this research refers to a novel. The word 'novel' itself comes from an English word that is 'novel' as well. It is a fictional prose which presenting characters, a series of events, and structured setting. As an imaginative work, it reveals profound aspects of humanity and presents it subtly. Not only as an entertaining tool, but it is also an art form which observes and examines the aspects of life and good or bad deeds (morals) where it directs the readers to find what noble character is (Sudjiman, 1998, p.53).

A novel by Sayuti (2000, p.7) is categorized as a formal fictional work. For general readers, this categorization can ascertain that any form of fictions is created with the aim of specific occasions. Thus, readers will appreciate literature better.

Novel is an exploration or a chronicle of life, reflecting and describing in a certain form which also includes the influence, bond, result, destruction or achievement of human movements (Virginia Woolf in Purba, 2007, p.62-63). Nurgiyantoro (2012, p.10) suggests that novel is a work of fiction built by constructing elements that is intrinsic and extrinsic element. It is also interpreted as an essay in the form of prose containing a series of stories of one's life with others around him by highlighting the character and habits. It is a type of literary works written in narrative form which contains certain conflicts in the story of the characters' life.

Novel in the literary world is classified into two types, namely serious and popular novel. Serious novel or better known as literary novel is a type of work which worth to be discussed. It must be able to provide all possible things, which is called literary meaning. It also aims at providing entertainment, valuable experiences, and inviting readers to deeply appreciate about the issues presented (Nurgiyantoro, 2012, p.18).

Unlike popular novels which always follow market preferences, literary novels are not devoted to readers. Literary novels tend to expose more serious themes. The texts often express something implicitly which is assumed to occupy readers. Nurgiyantoro (2012, p.18) reveals that in reading a serious novel, if you want to understand well, it requires high concentration accompanied by a will for it. This type of novel, in addition to providing entertainment, also implicitly aims at providing a valuable experience to readers or at least inviting them to deeply absorb and reflect on the issues offered.

Based on the previous definitions, this research tends to follow Virginia Woolf's, because it is in accordance with the research objectives which focus at the activities of story characters in their lives, especially female characters.

\section{B. Feminism in a Novel}

Defining feminism, we will begin with the definition by British novelist and journalist, Rebecca West. She uttered, "I myself have never been able to find out what feminism is; I only know that people call me a feminist whenever I express sentiments that differentiate me from a doormat or a prostitute." (Rebecca West, a book and an author) quoted in Jha (2016).

Feminist critics and writers are always surprised to know about women position in society because they write quite a lot about this. Those true facts and current trends do not reduce their exploration interests, but rather improve their mode of research and refine their specialties. This is because women write what men cannot show through their writing. Women's writing about women itself is highly valued in this contemporary and post-modern era. Post-modernism is an era where women can strengthen their voices and claim the differences they suffer in society. 
Femininity is generally understood as an aspect of socially constructed gender identity which is related to women or women's characteristics (Ahmed, 2018). MacKinnon in Ahmed (2018) traditionally confirms that 'womanhood means femininity, as an attraction for men, and sexual attraction, or sexual availability for men. In this view, as explained by Talbot (2010, p.137) in Ahmed (2018), femininity is nothing but a matter of sexuality, the problem of women who see themselves from a male perspective and regard their sexuality as an important social identity.

One of the unique characteristics of feminism where also becomes its strength and weakness is its constant defiance which limited by the definition. Charlotte Witt observes that this reflects "the debated nature of" us "contemporary feminism ... and is part of the ongoing debate within feminism over identity and self-image ... in the last analysis, the results of the debate in feminist philosophy about the feminism, what is the theoretical commitment, and what are the core values (Yeseibo, 2018).

Feminism and literary work cannot be separated. Literary work as a human's creative work consists of poetry, prose, and drama which contains various forms of life. The form of human life is then processed into creativity in three forms of literary work which also contain feminist ideology.

The thoughts and movements of feminism were born to end male domination that occurred in society. Through feminism projects (thoughts and movements), the structure of culture, art, church, law, nuclear family based on the patriarchal and state authority must be destroyed, as well as all images, institutions, customs, and habits that make women as victims who are not valued and concealed (Ruthven, 1985: 6).

Feminism is an understanding which combines the doctrine of rights equality for women into an organized movement to achieve women's rights, with an ideology of social transformation aiming at creating a space for women. Furthermore, Humm states that feminism is the ideology of women's liberation in the belief that women experience injustice because of their gender. It offers various analysis of the causes, perpetrators of such oppression of women according to Humm's (2007: 157-158).

Feminism is an ideology developed in various parts of the world, including in Indonesia. It has also entered the spaces of life, encompassing literary works. Basically, it is an ideology that empowers women where they can also be subjects in all fields by using their experiences as women and using perspective which are free from the mainstream of patriarchal culture that often goes from men's view.

Feminists recognize that their movement is rooted from women's awareness, because they are often in a state of being oppressed and exploited which must be ended. In addition, the feminism movement aims at fighting for equality and status as men, also the freedom to control their own body and life both inside and outside the household.

Harsono in Mustaqim (2008, p.84) clarifies that feminism is actually a concept arises in relation to social change, development theories, women's political awareness, and women's liberation movements including to readdress family institutions in the context of current modern society. Mustaqim (2008, p.85) adds that feminism is an understanding for respecting women so that their rights and roles are more optimal and equal, no more discrimination, marginalization, and subordination.

In line with the statement, Bashin and Khan in Mustaqim (2008, p.4) confirm that feminism is defined as an awareness of women oppression and extortion in society, whether at working environment and in the family, as well as conscious actions by women and men to change the situation into a living condition of harmony between both genders, free from all forms of subordination, marginalization, and discrimination.

Feminism is not a rebellion against men, an attempt to fight social institutions such as domestic institutions and marriage, or women's efforts to deny their nature, but rather an attempt to end women oppression and exploitation. In this case, the goal of feminism is not just a matter of gender, but to fight for human rights. Its movement is a struggle to transform unfair social systems and structures into justice for both men and women (Fakih, 2013, p.78-79). Therefore, feminism wants women's independence which not merely depending on men.

\section{Ideological Feminist Literary Criticism}

Ideological feminist literary criticism involves women as readers. This criticism examines misconceptions about women and the reasons why they are often not taken into account. To emphasize, it is a criticism that involves women, especially feminists as readers where their center of attention is an image and stereotype of a woman in literary works.

This criticism also examines why women are mostly neglected. Basically, a variety of ideological feminist criticisms is a way of interpreting a text, which is one of the many ways that can be applied to even the most complex texts. This method not only enriches the insight of female readers, but also frees their way of thinking (Djajanegara, 2000: 28).

\section{Women's Image}

Women's image is all forms of mental spiritual images and daily behavior expressed by female figures. Whether it is an individual being which includes both physical and psychological aspects, as well as the image of women in social aspects (Sugihastuti, 2000, p.7). The image can be seen through the role that they play in daily lives. If it is found in literary works, especially in the form of prose, then the image can be seen from the life of the main female character and also through other figures involved in the life of the character featured in the literary work. By this point, Ali (1989, p.123) divides the image of women as a benchmark into the following types:

a) An Image of Traditional Women 
The characteristics of traditional-image women are (1) not being educated, (2) less rational, (3) too dependent on men, (4) not free and bound by family, customs, and religious values in dogma.

b) An Image of Modern Women

The characteristics of modern women are influenced by western culture with the following, such as: (1) educated, (2) rational, (3) not static and wanting to move forward, 4) not depend on men, (5) more concerned to environment, (6) free from family ties, customs, and are individual, (7) and some of them deviate from religious teaching.

c) An Image of Transitional Women

The characteristics of this type of women owned by both traditional and modern women. They have characteristics as traditional and modern women at once.

The image of feminist women is a female figure who is portrayed to bring feminist concepts or ideas. In their image, these women figures struggle to detach from oppression, marginality, subordination, violence, and all forms of burden that make their lives backward and alienated. They are female figures who dare to make changes according to their wishes (Muslimat, UNHAS repository).

\section{RESEARCH METHODOLOGY}

This type of research is qualitative research with descriptive method using feminist literary criticism approach. The data used in this research are words, phrases, clauses, sentences, and discourses in which there are characteristics of women's images. The research data source is the novel of Entrok by Okky Madasari. The applied technique of data collection is content analysis, while technique of validity is source triangulation. For technique of data analysis used in this research is an interactive analysis model with three components of data reduction, data presentation, and conclusion drawing.

\section{RESEARCH FINDINGS}

\section{A. A Self-image of Marni}

Physically, Marni's character is depicted only at the age of her early adolescent marked by changes in body shape as in the following excerpt:

(1) "Kumulai ceritaku saat aku mulai kenal dunia di luar Simbok. Saat tinggiku sudah sepundak Simbok dan tangan kananku bisa meraih kuping dengan mudah. Saat itu aku menyadari ada sesuatu yang berbeda di dadaku. Ada gumpalan yang lembut dan terlihat menyembul dari balik baju yang kupakai. Simbok bilang aku sudah mringkili. Kataya itu hal biasa yang akan dialami seтиa perempuan. Kataya mringkili adalah salah satu tanda aku sudah bukan anak-anak lagi." (Madasari, 2016, p.15-16).

Translation:

"I begin my story when I started to know the world outside Simbok. When my height was Simbok's shoulders and my right hand could reach my ears easily. At that time, I realized there was something different in my breast. There was a soft lump and appeared to pop from behind the clothes I was wearing. Simbok says I have mringkili (grown up). She said it was a normal thing that will be experienced by all women. She added that mringkili is one sign that I am no longer a kid." (Madasari, 2016, p.15-16)

Marni is psychologically described as a hard-working woman who determined to change her life by improving her family's economy. This thought has grown since Marni reached her adolescence. Starting when Marni joined Simbok and helped her to peel cassavas which belonged to Nyai Dimah.

(2) "Hari-hari berikutnya, Nyai Dimah seperti menjadi majikan tetap kami. Setiap hari selalu ada singkongsingkong Nyai Dimah yang dikupas. Dan entah kenapa tidak ada orang lain yang mengupas singkong itu lebih dulu sebelum kami datang" (Madasari, 2016, p.25).

Translation:

"The following days, Nyai becomes like our permanent employer. Each day there were always cassavas from Nyai Dimah to be peeled. And for some reason, no one else peeled the cassava before we came." (Madasari, 2016, p.25)

Marni's desire to work was stronger. She was willing to be a porter which was a man's work. Marni was not satisfied just being a cassava peeler and paid for cassava in return. She wanted to get a salary like men were paid for money.

(3) "Ni, kamu ada-ada saja. Nggak ada perempuan nguli. Nggak akan kuat. Sudah, perempuan itu kerja yang ringan-ringan aja. Ngupas singkong."

"Aku kuat Kang. Biasanya aku juga nggendong tenggok, nggendong goni. Bakul-bakul itu juga banyak yang mengangkat sendiri dagangannya dari rumah ke pasar. Hanya priyayi-priyayi saja yang nggak kuat ngangkat goni."

"Tapi tetap nggak umum, Ni. Di pasar ini, nggak ada perempuan nguli."

"Tapi aku mau, Kang. Aku butuh duit, Kang. Nggak mau lagi diupahi singkong." (Madasari, 2016:34)

Translation:

"Ni, seriously. There is no 'nguli' (porter) women. They won't be strong. Come on, women just work lightly. Peeling the cassava." 
"I'm strong, Kang. Usually I also carry 'tenggok' (basket), gunny sacks. The baskets were mostly and often carried from house to market. Only 'priyayi' (upper classes) are not strong enough to lift gunny sacks."

"But it's still unfamiliar thing to do, Ni. In this market, there are no women who works that hard."

"But I want, Kang. I need money, Kang. I don't want to be paid with cassava anymore." (Madasari, 2016, p. 34)

The data excerpt (2) and (3) clearly indicate the desire of the author to show the image of a woman who dares to change the rules, as well as the way the author speaks the injustice experienced by women for their soft and weak physical and psychological images. Through the character of Sumarni, the author portrays a strong and brave woman who strives to change her life for the better.

Marni's actions which dare to oppose the prevailing system in her society, such as being the first female porter in the market, show that she is a free-minded woman. She does not want to be shackled by the habits of the Singget community. It shows a woman's perseverance to achieve dreams by changing a habit.

(4) "Aku yang satu-satunya perempuan di antara kuli-kuli itu langsung merasa wanita itu memanggilku. Inilah kiranya orang yang akan pertama kali memberiku uang.” (Madasari, 2016, p.38)

Translation:

"I was the only woman among the porters who immediately felt that the lady calling me. This is the person I guess who will first pay me with money." (Madasari, 2016, p.38)

The figure of Marni was not satisfied with her work as a female porter, so she began to think about changing jobs again with bakulan (carrying baskets) but not in market. She had the idea of selling it by directly going to customers.

(5) "Simbok, aku sudh memikirkan semuanya. Aku akan bakulan, tapi tidak di pasar. Aku akan menjual daganganku di sepanjang jalan pasar sampai ke Singget, lalu berkeliling dari rumah ke rumah yang ada di Singget. Siapa yang masih memilih jauh-jauh berjalan ke pasar kalau ada yang mengantar dagangan sampai ke pintu rumah?"(Madasari, 2016, p.43-44).

Translation:

"Simbok, I have thought about everything. I will do 'bakulan', but not in the market. I will sell my wares along the market road to Singget, then visit from house to house in Singget. Who still chooses to walk all the way to the market if there is someone who delivers the wares to their houses?" (Madasari, 2016, p.4344)

The problem of the psychological aspect of marriage interferes with Marni's thoughts. She was afraid because in reality she saw that marriage would bring misery. The fear arose based on the story of Marni's customer about her household life. Marni then initially refused to get married.

(6) "Tapi cerita-cerita itu juga menimbulkan ketakutan. Takut pada laki-laki, takut kawin. Lha buat apa kawin, kalau jadinya cuma sengsara. Inilah yang kukatakan pada Teja waktu dia memintaku jadi istrinya. Dia melamarku di depan pasar, saat matahari baru mengintip malu-malu, saat aku menunggu kedatangan petani yang membawa berbagai sayur-sayuran. Aku belum mau kawin, Kang.” (Madasari, 2016:47) Translation:

"But the stories also cause fear. Fear of men, fear of marriage. Why do you marry, if it becomes only miserable? This is what I told Teja when he asked me to be his wife. He proposed to me in the market, when the sun was just peering shyly, as I awaited the arrival of a farmer carrying vegetables. I don't want to marry, Kang." (Madasari, 2016, p.47)

Marni's fear of marriage is supported by anxiety of a fate that her future children will be like hers. Marni does not want the hardness of life to befall her children. Her strong principle of marriage finally melted after Simbok advised her that a woman must have a husband and children, because marriage demands for women not to become spinsters. Marni finally complied with what Simbok said.

(7) "Punya 2 anak? Bagaimana jika aku punya anak nanti? Mau jadi apa anakku nanti? Tukang kupas singkong atau bakulan keliling desa kalau perempuan? Anak laki-laki ikut bapaknya nguli?. ,

"Nduk, anak perempuan itu harus punya suami, punya anak. Kalau sudah ada yang melamar tidak boleh ditolak, bisa kualat, jadi perawan tua.” (Madasari, 2016, p.47-48)

Translation:

"Having 2 children? What if I have a child later? What will my child want to be? Is it peeling cassava or doing 'bakulan' around the village if it is a girl? And if it is a boy, he will come along with his father?

"Nduk, a woman must have a husband, have children. If there are a man proposing to you, he should not be rejected, you can be accursed if you don't accpet, becoming a spinster." (Madasari, 2016, p.47-48)

As a wife, Marni respects her husband even though Teja does not carry out his role as a good husband. He only used Marni's wages to commit adultery with other women.

(8) "Dasar Teja, lanangan nggak tahu diuntung. Susah payah aku cari duit, dia malah enak-enakan kelonan sama kledek.” (Madasari, 2016, p.53) 


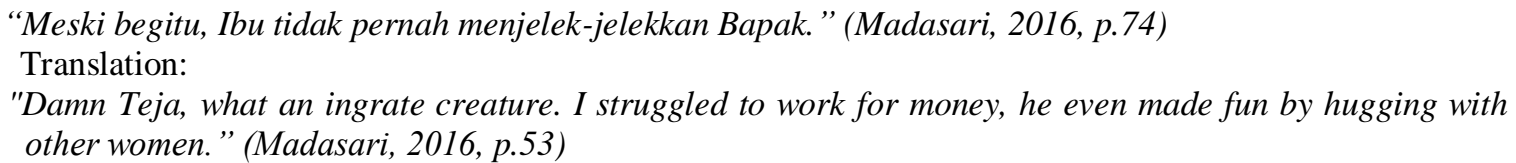

“Even so, I never blamed him." (Madasari, 2016, p.74)

\section{B. A Social Image of Marni}

As a wife image, Sumarni is described as the one who does not depend her life on husband. She actually becomes a wife who had more roles in making a living for the family. Sumarni is a mother who is truly aware of the education importance for her children, even though she is not educated. Marni's wish that her children later become a scholar and will have a better profession which encourages her to be more active in developing her work.

Marni's image as a wife is depicted by the figure who plays a major role in regulating household affairs as well as selling her bakulan business while her husband, Teja, just obeys what she says as in the following exerpt:

(9) "Teja tidak pernah tahu berapa keuntungan yang kami dapat, dia juga tidak pernah meminta. Dia juga tidak tahu apa saja dagangan yang harus dikulak, berapa harganya, dijual berapa. Yang dia tahu hanya mengangkat goni di punggung." (Madasari, 2016: 49)

Translation:

"Teja never knew how much profit we achieved, he also never asked. He did not know what merchandise should be repaid, how much it would cost, how much to sell. All he knows is only lifting burlap on his back." (Madasari, 2016, p.49)

Because Marni is very aware of the education importance, she works as hard as she can to collect money for her children. She dominates the business of earning a living compared to her husband, Teja.

(10) "Selama dua puluh tahun, aku selalu mendengar Ibu bercerita tentang susahnya mencari uang. Tentang cerita zaman dulu, saat dia berjalan kaki ke pasar Ngranget. Tentang hidupnya yang melarat, sampaisampai tidak bisa beli BH. Ibu selalu mengulangi cerita itu disertai kainginan agar anaknya sekolah, biar jadi pegawai. Dia akan mengeluarkan uang berapa saja agar aku sekolah. Tak peduli dia mencarinya dengan susah payah.” (Madasari, 2016, p.53-54)

Translation:

"For twenty years, I've always heard my mother telling me about the struggle of collecting money. About the story of old times, when she walked to the Ngranget market. About her destitute life, to the point of not being able to buy a single breast holder. Mother always repeated the story with the wish to have her children go to school, to become an employee. She was willing to spend much money so I would be able to go to school. No matter how hard she tried for it." (Madasari, 2016, p.53-54)

(11) "Aku tahu Ibulah yang mengeluarkan keringat paling banyak atas apa yang didapatkannya ini. Bapak hanya membantu, mengantar ke pasar setiap hari, menemani Ibu menagih utang dari satu rumah ke rumah lain." (Madasari, 2016, p.74)

Translation:

"I know that my mother was the one who sweated the most for what she had obtained. Father only helped the rest, drove to the market every day, accompanied her to collect debts from one house to another." (Madasari, 2016, p.74)

Marni's role in the community was portrayed as a rich woman in Singget, where she became a loan shark. She employed men in his sugar cane plantation. She has also succeeded in changing lives from the abyss of poverty into a woman who has various properties. Marni aspires to change women's wages equal to men's.

Marni's role in society was increasingly known as the loan shark who provides loans to people in need.

(12) “Siapa to yang nggak tahu Marni Juragan Renten...? Semua tahu.” (Madasari, 2016, p.80) Translation:

“Who doesn't know Marni as Juragan Renten (loan shark)...? Everybody knows her.” (Madasari, 2016, p.80)

As previously stated that Marni employed many male workers in her sugar cane plantation and felt that she had succeeded in changing her life to give wages to men as the following excerpt:

(13) "Pekerja-pekerja itu duduk mengelilingiku sambil menuang teh dari cerek ke gelas. Aku berdiri di tengah mereka yang semuanya laki-laki. Dan aku sekarang akan mengupahi mereka. Simbok, lihatlah anakmu ini sekarang. Kita dulu bekerja memeras keringat seharian, diupahi telo, bukan uang, hanya karena kita perempuan. Lihatlah sekarang, anakmu yang perempuan ini, berdiri tegak di sini mengupahi para lakilaki. Setiap orang mendapat upah tujuh ratus dari uang yang kumiliki sendiri" (Madasari, 2016, p.102103).

Translation:

"The workers sat around me pouring tea from the kettle into the cups. Now I stand in the midst of all of them, men. And I will now reward them. Simbok, look at your child now. We used to work to sweat all 
day, paid for 'telo' (yams), not money, just because we are women. Look now, your daughter, standing up here hiring men. Everyone gets seven hundred of my own money." (Madasari, 2016, p.102-103)

Marni wants to help women to work and get the same wages as men, if someday she can buy more land. Marni is very concerned about the fate of women that she wants to equalize the rights of women from men by giving equal wage. Marni's desire reflects a criticism of the injustices experienced by women. This can be seen in the following excerpt:

(14) "Sayangnya tidak ada buruh perempuan di sini, betatapapun ingin aku mengupahi mereka dengan uang sebesar buruh laki-laki. Upah yang besarnya sama, tidak lebih kecil hanya karena dia perempuan, lebihlebih hanya diupahi dengan telo. Tapi taka da perempuan yang ikut menebang tebu. Tebu hanya menjadi jatah buruh-buruh laki-laki. Bagian buruh perempuan hanya nderep atau mbethot kacang. Tapi coba tanya ke perempuan-perempuan itu berapa upah yang mereka dapat. Paling-paling tak lebih daripada tiga ratus sehari. Sayangnya, aku tidak menanam padi atau kacang. Kalau Mbah Ibu Bumi Bapa Kuasa mengizinkan, semoga rezekiku dilancarkan, aku punya duit untuk membeli tanah lagi yang akan kutanami padi dan kacang. Aku pekerjakan perempuan-perempuan itu dan kuberi upah tak kurang daripada yang diterima suami-suami mereka." (Madasari, 2016, p.103)

Translation:

"Unfortunately there are no female workers here, however they want me to pay them with money as big as male workers. Wages of the same amount, not smaller because they are women, or even paid by 'telo'. But there are no women who come to cut down sugar cane. It is only a part of male workers. The female laborers' share is only digging peanut. Try asking the women how much they are paid. At least not more than three hundred a day. Unfortunately, I'm not growing rice or beans. For Mbah Mother Earth and Father permit, hopefully my fortune will run smoothly, I have the money to buy more land that will be planted with rice and peanuts. I will employ these women and pay no less than what their husbands receive." (Madasari, 2016, p.103)

The excerpt above explains the position of women who are not properly distinguished from men, for example in terms of wage payment. The right between men and women must remain the same in the division of labor and wages. The thought of Marni figure is a representation of the demand for the phenomena that still occur today.

\section{An Image of Transitional Woman}

The image of a transitional woman in Entrok novel is portrayed by Sumarni or Marni. She has the characteristics of a traditional woman and also the nature of modern one. The traditional side of Marni is showed by her uneducated figure but has growth-mind which is described in data excerpt (14). By recognizing the importance of education, Marni works hard to be able to finance her children later for school in data excerpt (10). She is also an independent woman who does not depend on men, even she is the one who works hard outside the home as seen in data excerpt (2), (3), (4), (5), (9), and (11).

\section{An Image of Feminist Woman}

The image of Marni where she shows the image of a feminist marked by her thoughts who willing to pay women as equal to men. In Marni's view, there are no rights separation to obtain employment and wages between men and women. She expects her children to study and not to become like her who is uneducated. She is also very determined to change her life from the poverty gap to the position of woman who has dignity in society. Marni finally manages to own property and employ many farmers in her land. She is also managed to send Rahayu, her daughter, to go to college even though she did not finish due to activism involvement which oppose the government and leads her to be imprisoned. However, the thoughts of Marni reflect the image of a feminist woman.

\section{DISCUSSION}

The story characters in the novel present their respective images. In the novel Entrok by Okky Madasari, Sumarni or Marni character is portrayed by an uneducated woman. She is illiterate and poor but her willingness to change her life is strong only to get out of poverty. Sumarni even chose a job as a market porter. A type of work that was never done by a woman in her village. For the people of Singget, women are only suitable to be cassava peelers and cannot choose jobs that only men can do.

The female character told in the novel Entrok by Okky Madasari, Marni, is an illiterate woman who strives to change poverty in her life where she works as a cassava peeler, female porters, money lender or loan shark that bring her to become a rich woman in Singget. The characteristics of the female image in Entrok are revealed through Marni's selfimage and social image.

Sumarni's character in the novel Entrok portrayed as a transitional woman with the character according to Ali (1989: 123) of traditional and modern woman at once. Sumarni is categorized as a transitional woman because if considering her level of education, she has never received education at school where she is still bound by the customs and dogma she adheres to. This characteristic is included in the type of a traditional woman. But then, she has growth-mind, rational, independent from men, more concerned with her surrounding, free from family ties which belong to the characteristics of a modern woman. 
She has a desire to move forward by wanting to change their economic status for the better. Marni wants to be a porter so that her life does not depend on her Simbok (mother).

Freedom to act with the courage of Marni against the rules in her society concerning the view that women cannot be porters, is a form of desire that is not bound to the family or customs that they understand. Marni wants to live independently to adjust the situation she experienced where her actions are categorized as the image of a modern woman. That is why in Marni figure, it is seen from the physical and psychological images including the image of transitional woman.

\section{CONCLUSION}

Based on the results of the analysis, we discover the image of female characters or self-image which includes physical image, psychological image, and social image concluding that Marni also possesses a transitional female character. In addition to her role as a transitional woman, she is also portrayed as a feminist woman. On the whole, Marni has two positions as a transitional and feminist woman.

\section{REFERENCES}

[1] Ali, A.Wahab. (1989). Imej Manusia dalamSastra. Kuala Lumpur: Dewan Bahasa dan Pustaka.

[2] Bhasin, Kamla dan Nighat Said Khan. (1996). Persoalan Pokok Mengenai Feminisme dan Relevansinya (edisi terjemahan S. Herlinah). Jakarta: Gramedia.

[3] Chandrasekara, P.V. Sashini. (2016). Interantional Journal of Language and Literature. Edisi Juni, Vol. 4(1), pp. 160-166. (Gender issues discussed in Sri Lankan and Indian plays: Special reference to Edirivira Sarachcahndra's 'Maname' and Jaishankar Prasad's 'Dhruvasvamini'.

[4] Djajanegara, Soenarjati. (2000). Kritik Sastra Feminis: Sebuah Pengantar. Jakarta: Gramedia Pustaka Pelajar.

[5] Fakih, Mansour. (2013). Analisis Gender dan Trasformasi Sosial. Yogyakarta: Pustaka Pelajar.

[6] Humm, Maggie. (2007). Ensiklopedia Feminisme. Edisi Bahasa Indonesia diterjemahkan oleh Mundi Rahayu. Yogyakarta: Fajar Pustaka Baru.

[7] Madasari, Okky. (2016). Entrok. Jakarta: Gramedia.

[8] Mustaqim, Abdul. (2008). Paradigma Tafsir Feminis: Membaca Al-Quran dengan Optik Perempuan: Studi Pemikiran Riffat Hasan tentang Isu Gender. Yogyakarta: Logung Pustaka.

[9] Nurgiyantoro, Burhan. (2012). Teori Pengkajian Fiksi. Yogyakarta: Gadjah Mada University Press.

[10] Purba, Antilan. (2007). Sastra Indonesia Kontemporer.Yogyakarta: Graha Ilmu.

[11] Purwanti, Ani (2009). Feminisme Merubah Masyarakat. www.suaramerdeka.com. accesed on 3 Februari 2018.

[12] Ruthven, K.K. (1986). Feminist Leterary Studies an Introduction. Cambridge, New York, Port Chester, Melbourne, Sydney: Cambridge.

[13] Sayuti, Suminto A. (2000). Berkenalan dengan Prosa Fiksi. Yogyakarta: Gama Media.

[14] Sudjiman, Panuti. (1998). Memahami Cerita Rekaan. Jakarta: Pustaka Jaya.

Irna Fitriana, S.S., S.Pd., M.Pd. Born in Watampone on February 18, 1973. Start of primary education in SD Negeri 24 Macanang Bone Regency 1979 until 1984. and 1984 to 1985 in SD Ivi. 10/73 Ceppaga Sub Libureng Bone Regency. The first secondary school in junior high Country Libureng Bone Regency years 1985 to 1988. High school in SMA Negeri 1 Watampone years 1988 to 1991. In 1991 entered Faculty of letters Department of Literature at HASANUDDIN UNIVERSITY Makassar, Indonesia finished tahun1996. In 2006 took the ACT IV in Muhammadiyah STKIP Bone. Continuing education S-2 in 2009 and completed in 2011 at the Makassar State University Graduate education courses Indonesian Language. In the doctoral program in 2014 taking State University Makassar Indonesian Language education courses.

Since 1998 until now became a lecturer at the Muhammadiyah Bone STKIP Foundation. Extraordinary lecturer in Bataritoja Bone Regency AKPER years 2006 till now and IAIN Watampone year 2013 until now.

Achmad Tolla, Lecturer of the Faculty of language and literature of IKIP/Makassar State University year 1982 till now, born in Leling Mamuju Regency, March 21, 1949. Completed primary school education Affairs Leling year 1966, the first State secondary school of the year 1968, Mamuju, Mamuju Sman 1970, B.a. IKIP Ujung Pandang years 1979, S-1 IKIP Ujung Pandang year 1981, Then completed S-2 FPs IKIP Malang 1991. Won a doctorate FPs Ikip Malang in 1996.

The experience of the Office, the head of the laboratory of FBS IKIP Ujung Pandang years 1996-1997, Secretary of the Program S-2 PPs IKIP Ujung Pandang years 1997-2001, Assistant Dean UNM FBs year 2001-2004 III, Chairman of the Indonesian Language Education 2004-2005 years, UNM Head UPBJJ UT West Sulawesi years 2005-2008, Chairman of the Doctoral Program of the science of language education PPs UNM year 2009 s. d now, Presiding Professor State University of Makassar.

Jasruddin, Lecturer in the Department of physics at the State University of Makassar. Place date of birth, Matano 22 Desembar 1964, the formal State primary school biennial donations Matano 1973-1975. 220 Sorowako Lands elementary school 1975-1979. Middle School State Nuha 1982. Inco mine Soroako middle school, 1985. Then continue on S-1 physics education IKIP Ujung Pandang years 1990, S-2 physics education Bandung Institute of technology of the year 1996, the S-3 (Ph.d.) major in physics education Bandung Institute of technology of the year 2002. 
The experience of the Office of the Director of the Graduate School of the State University of Makassar (UNM), Coordinator of the South Sulawesi Region X Kopertis year 2017 s. d now. Areas of expertise namely physics semiconductor materials especially amorphous silicon (a-Si) Thin Film Transistor for manufacturing (TFT), Thin Film Light Emitting Diode (TFLED), and a Solar Cell (solar cell).

Mahmudah, M. Hum was born on February 12, 1967 in Cantuk village. Singajuruhs subdistrict. Banyuwangi Regency. D-3 education completed in 1989 and S-1 year 1991 in Indonesian language and Literature Department IKIP Ujung Pandang. S-2 (9995) and the year 2005 completed the S-3 program in UNHAS in Sociolinguistic fields. The main task is the lecturer in Indonesian and regional language and Literature department, FBS of Makassar State University. 